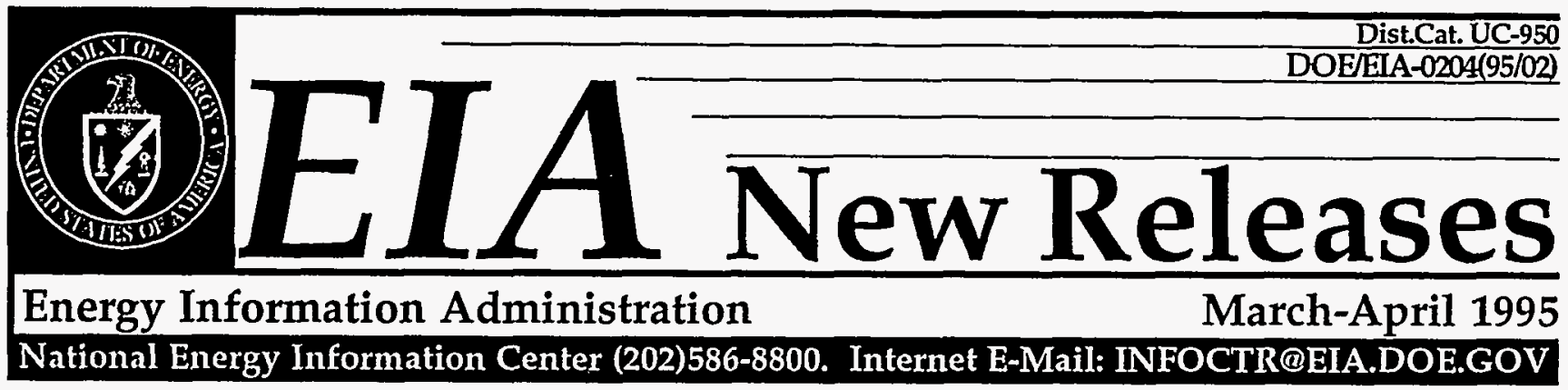

\title{
EIA Examines the Growing Importance of Longwall Mining
}

Longwall mines, which are more efficient than traditional "room-and-pillar" mines, increased their market share from 27 to 40 percent of U.S. underground coal production during the period 1983 to 1993, according to a report released by the Energy Information Administration (EIA).

The report, Longwall Mining, finds that the productivity of longwall operations more than doubled over the same period, from 1.59 tons to 3.30 tons per miner per hour. The productivity gains resulted primarily from technological improvements that allowed longwall mines to operate on an increasingly large scale.

In the latest longwall operations, state-of-the-art equipment is used to excavate and move the coal from a large "panel" or block of coal. Working under the steel canopies of movable roof supports, a coal cutting machine runs back and forth across the face of the coal panel. The cut coal spills into an armored chain conveyor that

\section{On the Inside}

\section{EIA Releases Consumption and} Expenditures Report ......... 2

The Natural Gas Industry and Underground Storage ........ 3

Electric Utility Fleet Survey 1993 Preliminary Estimates ....... 4

Features and Press Releases ...... 5

Microfiched Products ........ 7

Electronic Publishing System .... 8

New Reports .............. 9

Machine-Readable Files ........ 12

How To Order EIA Publications ... 13

Energy Data Information Contacts . . 15

Released for Printing: May 17, 1995 dumps the coal onto belt conveyors for transport out of the mine. The roof is allowed to collapse behind the supports as they are advanced. Mining continues in this manner until the entire panel of coal is removed.

Other major findings include:

West Virginia is the leading longwall mining State, with 21 longwall mines producing more than 30 million tons of coal in 1993.

* By 1993, longwall mining productivity was nearly 20 percent higher than productivity for other underground mining methods.

* The productivity advantage of longwall mining is greatest in the West, at 5.67 tons per worker-hour in 1993, compared with 3.76 tons per worker-hour for other (continued on page 3 )

\section{New Weekly Petroleum Data on EPUB}

Beginning with the data for the week ending April 14, tables from the Weekly Petroleum Status Report have been made available in a fixed- and comma-delimited format on EIA's Electronic Publishing System (EPUB).

Data presented include world crude oil prices, spot market product prices, average selling prices of motor gasoline and heating oil, U.S. petroleum balance sheets, etc.

See page 8 for detailed EPUB access instructions.

Printed with soy ink on recycled paper 


\section{EIA Releases Consumption and Expenditures Report}

The statistics published in the report Commercial Buildings Energy Consumption and Expenditures 1992 are from a randomly selected sample consisting of approximately 6,600 commercial buildings. This sample, based on a multistage area probability design, supplemented by a list sample of "large buildings," "recently constructed buildings," and "special buildings" represents the 4.8 million commercial buildings in the United States as of the spring of 1992.

The Energy Information Administration (EIA) incorporated a longitudinal component into the 1992 "Commercial Buildings Energy Consumption Survey" (CBECS) by revisiting many of the same buildings that were sampled for the 1986 CBECS. The longitudinal data, which are not included in this report, provide an opportunity to study change in energy consumption between 1986 and 1992 at the building level. The EIA, however, will undertake an analysis of these longitudinal data at a later date.

The four major energy sources for which billing data were collected in 1992 were electricity, natural gas, fuel oil (including kerosene), and district sources (steam, hot water, or chilled water from a central plant or utility). The use of other energy sources in the building, such as propane, wood, coal, and solar energy, was also determined during the building interview. With the exception of wood, however, no consumption statistics were gathered on these energy sources.

The consumption and expenditures estimates for the major energy sources for 1992 are presented in the form of net aggregate totals as well as consumption per building and dollars per million Btu. All tables in the report include estimates for the amount of energy consumed at the site (site energy consumption) and two tables also include estimates of consumption after accounting for conversion and transmission losses that occur in the electricity generation process (primary energy consumption).

The report also includes estimates of energy intensities. Energy intensities provide a method for controlling or adjusting the amount of energy consumed for the effects of various building characteristics, such as size, number of workers, and number of operating hours. The adjustment facilitates comparisons of energy consumption across time, energy sources, and building types.

Estimates of energy consumption and expenditures, for the Nation as a whole and for individual Census regions, are provided for the following building characteristics:
* Building size (square feet of floorspace)
Building age (year constructed)
* Building structure (such as number of floors, type of wall and roof materials, and building shell conservation features)
* Building use (principal building activity, normal and additional operating hours, number of workers, etc.)

* Geographic location (four Census regions and the nine Census divisions) and climate zone (measured in terms of the 45year averages of heating and cooling degree-days)

* Energy sources used in the building (electricity, natural gas, fuel oil, district heat, and chilled water, propane, wood, coal, etc., with billing data obtained from the energy suppliers on the first five sources)

* Energy end uses (space heating, water heating, air conditioning, cooking, and manufacturing)

Equipment (types of equipment used for space heating and cooling, water heating, lighting, refrigeration, etc.)

Energy conservation and energy management practices, such as having a "dedicated" energy manager; reducing energy use during off-hours; participating in demand-side management programs; etc.

The numbers presented in the report are estimates; however, these estimates are based on data from EIA's 1992 Commercial Buildings Energy Consumption Survey (CBECS), which are the only source of national-level data on commercial building characteristics and related energy consumption.

The report is available from the U.S. Government Printing Office. For price and ordering information, please see pages 11 and 13. 


\section{DISCLAIMER}

This report was prepared as an account of work sponsored by an agency of the United States Government. Neither the United States Government nor any agency thereof, nor any of their employees, make any warranty, express or implied, or assumes any legal liability or responsibility for the accuracy, completeness, or usefulness of any information, apparatus, product, or process disclosed, or represents that its use would not infringe privately owned rights. Reference herein to any specific commercial product, process, or service by trade name, trademark, manufacturer, or otherwise does not necessarily constitute or imply its endorsement, recommendation, or favoring by the United States Government or any agency thereof. The views and opinions of authors expressed herein do not necessarily state or reflect those of the United States Government or any agency thereof. 


\section{DISCLAIMER}

Portions of this document may be illegible in electronic image products. Images are produced from the best available original document. 


\section{The Natural Gas Industry and Underground Storage}

Underground storage is a vital part of the natural gas industry. The ability to store gas ensures reliability during periods of heavy demand by supplementing pipeline capacity. Storage also enables greater system efficiency by allowing more level production and transmission flows. End-use customers gain from this increased efficiency with reduced overall costs of service.

The report The Value of Underground Storage in Today's Natural Gas Industry explores the significant and changing role of storage in the industry by examining the value of natural gas storage; short-term relationships between prices, storage levels, and weather; and some longer term impacts of the Federal Energy Regulatory Commission's (FERC) Order 636. ${ }^{1}$ Some of the highlights of the report include the following:

* Expected storage requirements and spot prices are strongly related during the heating season. High prices in the spot market are associated with low levels of storage relative to expected deliveries. As temperatures drop below normal, storage withdrawals increase and gas prices can rise dramatically. The premium value of having gas available for immediate delivery during periods of stress can be greater than $\$ 1.00$ per million British thermal units (Btu). During other times of the year, the relationship between storage and spot prices is much less direct as weather and pipeline capacity utilization are of less concern.

* Regulatory changes during the past decade have resulted in significant changes in storage operations. Higher utilization of storage facilities is evident throughout the year in both injection and withdrawal activities. However, new programs for storage markets, such as

\footnotetext{
'Issued in April 1992, FERC Order 636 requires for pipeline companies to provide open access transportation and storage and separate sales from transportation services. The Order also authorizes capacity release, electronic bulletin boards, and straight fixed-variable rate design.
}

market-based rates and secondary markets for storage capacity, have experienced limited growth.

Proposed capacity additions through the end of the decade could increase the ability of the storage industry to deliver gas from storage on a peak day by almost 31 percent from the level in 1993. About one-third of the proposed additions to working gas capacity are for high-deliverability salt cavern storage projects, which allow greater flexibility for both withdrawals and injections throughout the year than is available in more traditional facilities. The flexibility is increasingly valuable in addressing new market requirements.

The key role that storage plays in the natural gas market was demonstrated during January and February 1994 when severe weather placed enormous demands upon the industry. The additional storage capacity placed in service since the frigid December of 1989 played a role in allowing the successful delivery of gas to the markets during January 1994. The ability to deliver gas from storage has increased by nearly 10 percent over levels available in December 1989.

\section{Longwall Mining (continued from page 1)}

underground mines. Longwall mines accounted for about 80 percent of underground coal production in the West.

Longwall mining productivity is expected to grow further, as the technology continues to improve.

The report presents a brief history of longwall mining and measures important changes in the geologic, technological, and operating characteristics of U.S. longwall operations that have affected productivity. The report also discusses relevant legislative and regulatory developments and the outlook for longwall mining.

Copies of Longwall Mining are available from the U.S. Government Printing Office and from the National Energy Information Center (202)5868800 .

(EIA Press Release EIA-95-09, March 23, 1995.) 


\section{Electric Utility Fleet Survey 1993 (Preliminary Estimates)}

The following article is also presented in EIA's report Monthly Energy Review, April 1995.

For more information contact Jennifer Reichert on 202/586-5736. Internet: ireicher@eia.doe.gov.

In 1993, electric utilities with fleets of 10 or more vehicles operated a total of 201,836 fleet vehicles. ${ }^{1}$ By fuel type, those fleets consisted of 97 percent (196,241 vehicles) conventional-fuel vehicles, operating on motor gasoline or diesel fuel alone, and 1.9 percent (3,756 vehicles) compressed natural gas (CNG) vehicles, operating on CNG alone or on a combination of CNG and either motor gasoline or diesel fuel. The remaining 1,839 vehicles operated on methanol, ethanol, electricity, propane, and other alternative fuels. Of those vehicles, 237 were dedicated electric vehicles.

These preliminary estimates are based on data collected by the Energy Information Administration (EIA) on Form EIA-861, "Annual Electric Utility Report," Schedule VII (Fleet Vehicle Information). The survey consisted of a questionnaire mailed to all of the electric utilities operating in the United States in 1993. There are approximately 3,200 electric utilities that file Form EIA861. Of those, 997 electric utilities had fleets of 10 or more vehicles in 1993 and, therefore, also completed Schedule VII.

The survey was conducted as part of EIA's response to Section 407 of the Energy Policy Act of 1992, which directs EIA to collect data that will be useful to those who wish to manufacture, convert, sell, own, or operate alternative-fuel vehicles or facilities.

\section{Electric Utility Fleets}

The electric utilities were asked to provide the following information about their fleets: fleet size; distribution of fleet vehicles among size classes; fuel types; alternative-fuel technologies; and fleet-vehicle retirements, acquisitions, and conversions planned for 1994 (as of December 31, 1993).

\footnotetext{
'Form ELA-861, Schedule VII, was designed so that electric utilities operating fewer than 10 vehicles were not required to complete the survey. However, a small number of electric utilities submitted data on their fleets of less than 10 vehicles. Those data are included in the totals.
}

The responses showed the following:

Medium- and heavy-duty vehicles represented the largest portion ( 35 percent) of the electric utility fleets, followed by passenger cars and large pickup trucks.

* In 1993, electric utility fleets operated few alternative-fuel vehicles, with alternativefuel vehicles representing only 2.8 percent of the total fleet vehicles.

Although full-size vans represented only 6.2 percent of the electric utilities' fleet vehicles, the full-size van vehicle category had the largest percentage of alternativefuel vehicles.

The alternative-fuel providers, such as electric utilities, are expected to be among the first to use alternative-fuel vehicles, both because of the Energy Policy Act's mandate to do so and because of the opportunity to promote their energy source as a transportation fuel. Presently, however, alternative-fuel vehicles other than electric vehicles (for example, natural gas vehicles) are more practical and economical, and electric vehicle technology has not progressed to the point where a variety of vehicle types can be offered. For these reasons, there are very few electric vehicles operating in electric utility fleets.

\section{Alternative-Fuel Vehicles}

The electric utilities were also asked to provide detailed information on the use of alternative-fuel vehicles in their fleets:

Nearly half (43 percent) of the alternative-fuel vehicles in electric utility fleets are pickup trucks.

More than two-thirds of the alternativefuel vehicles being operated by electric utilities are fueled by compressed natural gas, possibly due in part to the fact that many electric utilities are opting to operate the more economical natural gas vehicles until electric vehicle technology develops further (only 4.2 percent are electric vehicles).

The complete report, EPACT Section 407 Data Program: The Vehicle Stock and New Survey Findings, will be available at the end of the year from the U.S. Government Printing Office. 标 
Reprints of special features (Feature Articles, Highlights, Energy Previews, EIA Data News, etc.) appearing in Energy Information Administration (EIA) reports are available free from the National Energy Information Center.
Below is a listing of the features published so far in 1995. For a listing of features published in 1994, please refer to the November-December issue of EIA New Releases, DOE/EIA-0204(94/06). tof
Highlights: Manufacturing Consumption of Energy 1991 (Monthly Energy Review)

Feature Article: U.S. Wind Energy Potential: The Effect of the Proximity of Wind Resources to Transmission Lines (Monthly Energy Review)

Feature Article: The Comparability of Resource and Reserve Data for Crude Oil, Natural Gas, Coal, and Uranium (Natural Gas Monthly and Petroleum Supply Monthly)

EIA Data News: The Response Analysis Survey: Evaluating Manufacturing Energy Consumption Survey Methodology (Monthly Energy Review)

Feature Article: Comparisons of Independent Statistics on Petroleum Supply (Petroleum Supply Monthly)

Highlights: Commercial Buildings Energy Consumption and Expenditures 1992 (Monthly Energy Review)

Energy Preview: Electric Utility Fleet Survey 1993, Preliminary Estimates (Monthly Energy Review)
January 1995

February 1995

March 1995

March 1995

April 1995

April 1995

April 1995

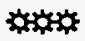

Periodically, the Energy Information Administration (EIA) issues press releases on current, highinterest issues. Copies of these releases are available from NEIC (202/586-8800).
Below is a listing of all EIA press releases prepared by EIA since the beginning of 1995 . For a listing of all 1994 press releases, see EIA New Releases, DOE/EIA-0204(94/06).

\begin{tabular}{|c|c|c|}
\hline Press Release THile & Number. & Pate Issured \\
\hline $\begin{array}{l}\text { Full Report Assesses the Oil and Gas Resources of Fergana } \\
\text { Basin, Former Soviet Union }\end{array}$ & EIA-95-01 & $01 / 06 / 95$ \\
\hline Improved Technology Leads to Lower Energy Price Projections & EIA-95-02 & $01 / 13 / 95$ \\
\hline $\begin{array}{l}\text { Internet, Bulletin Board Speed Access to ElA's Short-Term } \\
\text { Energy Model }\end{array}$ & EIA-95-03 & $01 / 26 / 95$ \\
\hline $\begin{array}{l}\text { Major Energy Companies' Strategies After Arab Oil Embargo } \\
\text { Shift from Growth to Consolidation }\end{array}$ & EIA-95-04 & $01 / 31 / 95$ \\
\hline Reliability and the Changing Electric Power Industry & EIA-95-05 & $02 / 01 / 95$ \\
\hline $\begin{array}{l}\text { Natural Gas Wellhead Prices Expected To Remain Low in First } \\
\text { Half } 1995\end{array}$ & EIA-95-06 & $02 / 15 / 95$ \\
\hline $\begin{array}{l}\text { EIA Examines the Decommissioning of the U.S. Uranium } \\
\text { Production Facilities }\end{array}$ & EIA-95-07 & $02 / 23 / 95$ \\
\hline EIA Updates Reference on U.S. Coal & EIA-95-08 & $02 / 27 / 95$ \\
\hline EIA Examines the Growing Importar & EIA-95-09 & $03 / 23 / 95$ \\
\hline
\end{tabular}

t姲 
This report was prepared by the Energy Information Administration, the independent statistical and analytical agency within the U.S. Department of Energy. The information contained herein should not be construed as advocating or reflecting any policy position of the U.S. Department of Energy or of any other organization.

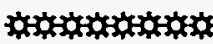

EIA New Releases is published six times per year and is available at no charge to anyone who requests it. Ask to be added to our mailing list by using the order form on the last page, by calling the EIA.'s National Energy Information Center on (202) $586-8800$, or by contacting us on Internet. Our E-mail address is:

$$
\text { infoctr@eia.doe.gov }
$$

This report is also available electronically from the following:

EPUB, EIA's electronic publishing system bulletin board (see page 8 for access information) EIA Home Page for Internet users (http://www.eia.doe.gov)

Inquiries or comments concerning the contents of this publication should be directed to the chief editor Ingrid Springer at (202)586-1100; questions concerning data, reports, and machine-readable files should be directed to the National Energy Information Center at (202)586-8800 between 9 a.m. and 5 p.m., Monday through Friday, eastern time. 


\section{Microfiched Model and System}

Documentation

The Energy Information Administration (EIA) model and system documentation reports are available in microfiche form; the agency does not formally print or distribute this category of reports. The Department of Energy's Office of Scientific and Technical Information (OSTI) in Oak Ridge, Tennessee, produces these reports in microfiche form and sends the microfiche to the
National Technical Information Service (NTIS). NTIS sells these documents in microfiche or hard-copy form upon request.

Following is a listing of all EIA reports that have been released to OSTI since the beginning of 1995. Future editions of EIA New Releases will provide updates on the latest available reports. For more information, contact the National Energy Information Center (NEIC) on (202)586-8800 or on Internet (E-Mail Address: INFOCTR@EIA. DOE.GOV).

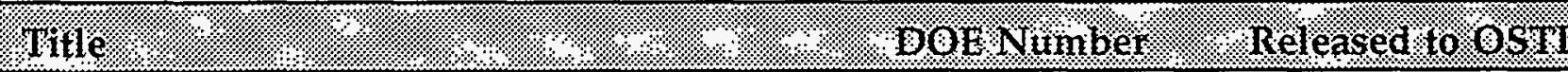

Model Documentation, Natural Gas Transmission and Distribution Model (NGTDM) of the National Energy Modeling System, Volume II: Model Developer's Report

Documentation of the Petroleum Market Model (PMM) Appendix: Model Developer's Report

Model Documentation, Renewable Fuels Module of the National Energy Modeling System, Appendix: Model

Performance

Documentation of the Oil and Gas Supply Module (OGSM) Appendix: Model Developers Report

Model Developer's Appendix to the Model Documentation Report: NEMS Macroeconomic Activity Module

Model Documentation Report: Residential Sector Demand Module of the National Energy Modeling System

Model Documentation Natural Gas Transmission and

Distribution Model of the National Energy Modeling System, Volume I

Model Documentation Electricity Market Module Modifications to the Electricity Capacity

Planning Submodule

Model Documentation Coal Market Module of the National Energy Modeling System
DOE/EIA-M062/2

January 1995

DOE/EIA-M059/A

January 1995

DOE/EIA-M069/A

January 1995

DOE/EIA-M063A(95)

March 1995

DOE/EIA-M065A(95)

March 1995

DOE/EIA-M067(95)

March 1995

DOE/EIA-M062/1(95)

March 1995

DOE/EIA-M068-B/1

April 1995

DOE/EIA-M060(95)

April 1995 


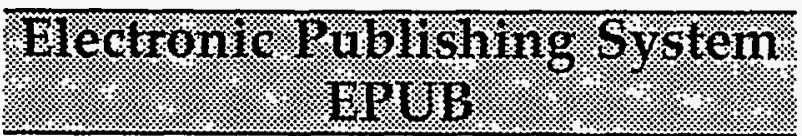

EPUB is an electronic publishing system maintained by the Energy Information Administration (EIA) of the U.S. Department of Energy. EPUB allows the general public to electronically access selected energy data from many of ElA's statistical reports. The system is a menu-driven, bulletin-board-type system with extensive online help capabilities that can be accessed free of charge 24 hours a day by using a terminal or PC with an asynchronous modem. (EPUB will be taken down briefly at midnight for backup.)

PC users must provide the following information to their communications software in order to successfully access the EPUB system:

Communications Parameters:

Baud Rate: Up to 28,800 bps

Data Bits: 8; Stop Bits: 1

Parity: None; Duplex: Full

Terminal Type: ANSI, ANSI-BBS, VT100, etc.

Once communications software and/or hardware have been configured, EPUB can be accessed by dialing (202)586-2557. When a connection to the system has been made, some users may find that the menu-driven instructions and the online capabilities will provide enough information to effectively use EPUB. More information may be obtained from:

National Energy Information Center, EI-231

Energy Information Administration

Forrestal Building, Room 1F-048

Washington, DC 20585

(202)586-8800

Internet E-Mail: INFOCTR@EIA.DOE.GOV

TTY: For people who are deaf or

hard of hearing: (202)586-1181

Hours: 9 a.m. to 5 p.m., M-F, eastern time
For communications or technical assistance, call (202)586-8959, 8 a.m. to 5 p.m. eastern time, Monday through Friday. For questions about the contents of EPUB reports and data, call (202)5868800,9 a.m. to 5 p.m., Monday through Friday, eastern time.

Following is a listing of some of the data and reports that are provided on EPUB:

Heating fuel data (April through September) Updated the second week of the month.

Oxygenate data

Updated approximately the 25th of the month.

Weekly Petroleum Status Report

Updated on Wednesdays (Thursdays in the event of a holiday) at 9 a.m.

Petroleum Supply Monthly

Updated between the 23rd and 26th of the month.

Petroleum Marketing Monthly

Updated on the 20th of the month.

Natural Gas Monthly

Updated on the 20th of the month.

Weekly Coal Production

Updated on Fridays at 5 p.m.

Quarterly Coal Report

Updated 60 days after the end of the quarter.

Electric Power Monthly

Updated during the first week of the month.

Monthly Energy Review

Updated the last week of the month.

Short-Term Energy Outlook

Updated 60 days after the end of the quarter.

Winter Fuels Report (October through April)

Propane inventory data updated Wednesdays at

5 p.m. All other data updated Thursdays (Friday

in event of a holiday) at 5 p.m.

Internet Access to EPUB

The EPUB system is not as yet directly accessible via Internet. However, Internet users can access EPUB via the FEDWORLD electronic bulletin board operated by the National Technical Information Service, Department of Commerce. The Internet address for FEDWORLD is <FEDWORLD.GOV>. Select "GATEWAY" from the main menu, and EPUB will be item 16 on that list. 


\section{Multisounce Energy}

\section{Monthly Energy Review}

This top-selling monthly publication presents a complete overview of the Nation's energy picture. It provides data on petroleum, natural gas, coal, electricity, nuclear energy, oil and gas resource development, prices, consumption, and the international energy situation. Appendices present thermal, metric, and other physical conversion factors.

DOE/ELA-0035(95/03), 188 pp., March 1995

DOE/EIA-0035(95/04), 188 pp., April 1995

Annual Subscription:

Domestic, $\$ 80.00$; Foreign, $\$ 100.00$

Single Issue: Domestic, $\$ 12.00$; Foreign, $\$ 15.00$

\section{Service Reports}

\section{An Analysis of Nuclear Power Plant Operating Costs:}

\section{A 1995 Update}

This is the third report on the subject published by EIA since 1988. The work was done at the request of the U.S. Nuclear Regulatory Commission, using data and methodologies deemed to be appropriate by EIA. Discussed in the report are the results of an analysis of nuclear power plant nonfuel operating costs. Nonfuel operating costs are composed of routine operating and maintenance costs and capital expenditures incurred after a plant begins operating.

SR/OIAF/95-01, 84 pp., April 1995

GPO Stock No. 061-003-00907-7

Domestic, $\$ 5.50$; Foreign, $\$ 6.88$

\section{PLEASE NOTE:}

Prices of EIA products sold by the U.S. Government Printing Office, the National Technical Information Service, or the Office of Scientific and Technical Information are subject to change without prior notice.

\section{Gleetricit:}

\section{Electric Power Monthly}

This report presents comprehensive monthly statistics at the national, Census division, and State levels for net generation, fossil fuel consumption and stocks, quantity and quality of fossil fuels, cost of fossil fuels, electricity sales, revenue, and average revenue per kilowatthour of electricity sold.

DOE/EIA-0226(95/03), 214 pp., March 1995

DOE/EIA-0226(95/04), 276 pp., April 1995

Annual Subscription:

Domestic, \$87.00; Foreign, $\$ 108.75$

Single Issue: Domestic, \$14.00; Foreign, $\$ 17.50$

\section{Natural Cas}

\section{Natural Gas Monthly}

This report provides monthly and annual information at the State and national levels on the supply and disposition of natural gas, including production, storage, import, export, and consumption data. Information is also given on the activities of the major interstate pipeline companies. Feature articles are included in certain issues to help readers use and interpret the information on natural gas.

DOE/EIA-0130(95/03), 120 PP., March 1995

DOE/EIA-0130(95/04), 110 pp., April 1995

Annual Subscription:

Domestic, \$78.00; Foreign, $\$ 97.50$

Single Issue: Domestic, \$9.00; Foreign, \$11.25

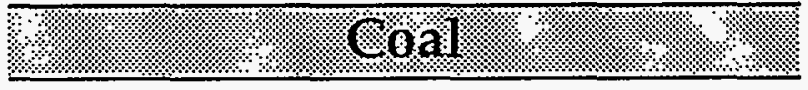

\section{Weekly Coal Production}

This short report provides timely information on coal production, as estimated by the Energy Information Administration from railroad car loadings.

DOE/EIA-0218(95-08)-(95-16), varied page count

March through April 1995

Annual Subscription:

Domestic, $\$ 85.00$; Foreign, $\$ 106.25$

Single Issue: Domestic, \$2.00; Foreign, $\$ 2.50$ 


\section{Petroleuin}

\section{Weekly Petroleum Status Report}

This weekly report, published each Wednesday, provides timely data on petroleum supply and disposition. The data are based on company submissions for the week ending at 7 a.m. the preceding Friday.

DOE/EIA-0208(95-09)-(95-17), varied page count March through April 1995

Annual Subscription:

Domestic, $\$ 65.00$; Foreign, $\$ 81.25$

Single Issue: Domestic, $\$ 3.50$; Foreign, $\$ 4.38$

\section{International Petroleum Statistics Report}

This report contains current international data on oil production, consumption, imports, exports, and stocks.

DOE/EIA-0520(95/03), 84 pp., March 1995

DOE/ELA-0520(95/04), 84 Pp., April 1995

Annual Subscription:

Domestic, $\$ 43.00$; Foreign, $\$ 53.75$

Single Issue: Domestic, \$4.50; Foreign, $\$ 5.63$

\section{Petroleum Supply Monthly}

This publication provides monthly statistics on petroleum supply, disposition, production, refinery operations, stocks, and transport.

DOE/ELA-0109(95/03), 169 pp., March 1995

DOE/ELA-0109(95/04), 180 pp., April 1995

Annual Subscription:

Domestic, $\$ 80.00$; Foreign, $\$ 100.00$

Single Issue: Domestic, \$12.00; Foreign, \$15.00

NOTE: In some instances, the month shown here may not correspond with the month shown on the cover or spine of a report. EIA New Releases lists the month that a report is RELEASED to the printer. However, some EIA report covers and spines display the date when the report is AVAILABLE to the public.

\section{Petroleum Marketing Monthly}

This publication provides price information on a variety of petroleum products, including motor gasoline, distillate fuel oil, jet fuels, kerosene, and propane. Sales data for petroleum products are also included.

DOE/ELA-0380(95/03), 216 pp., March 1995

DOE/EIA-0380(95/04), 204 pp., April 1995

Annual Subscription:

Domestic, $\$ 84.00$; Foreign, $\$ 105.00$

Single Issue: Domestic, \$14.00; Foreign, $\$ 17.50$

\section{Winter Fuels Report}

This seasonal report provides data on distillate fuel oil and propane net production, imports and stocks; natural gas supply, disposition, and underground storage; residential and wholesale pricing data for heating oil and propane; etc.

DOE/EIA-0538(94/95-20) through (94/95-25) March through April 6, 1995

Varied page count (free from the National Energy Information Center).

The April 6 issue was the last one for the 1994/1995 heating fuels season; it will resume in October for the 1995/1996 heating fuels season. The EIA is continuing to monitor propane stocks on a monthly basis, April through September. These data are available in the Weekly Petroleum Status Report.

\section{Tedhnical Reports}

\section{Longwall Mining}

This technical report describes longwall mining, compares it with other underground mining methods, and describes major changes in the geologic, technological, and operating characteristics of longwall mining over the past decade. The report also shows how these changes led to dramatic improvements in longwall mining productivity.

DOE/EIA-TR-0588, 72 pp., March 1995

GPO Stock No. 061-003-00903-4

Domestic, \$5.00; Foreign, $\$ 6.25$ 


\section{One Time Reports}

The Value of Underground Storage in Today's Natural Gas Industry

The report provides the latest available information on storage activities and analyzes important changes in the natural gas industry.

DOE/EIA-0591, 100 pp., March 1995

GPO Stock No. 061-003-00902-6

Domestic, \$6.00; Foreign, $\$ 7.50$

\section{Country Analysis Briefs: 1994}

This report is a compilation of country profiles for specific countries or geographical areas that are important to world energy markets.

DOE/EIA-0595, 108 pp., April 1995

GPO Stock No. 061-003-00906-9

Domestic, $\$ 6.50$; Foreign, $\$ 8.13$

\section{Energy Consumption}

\section{Commercial Buildings Energy Consumption and Expenditures 1992}

This report presents information on the energy consumption and expenditures of commercial buildings and is based on data collected on the 1992 Commercial Buildings Energy Consumption Survey (CBECS). The CBECS is the only source of national-level data on commercial building characteristics and related energy consumption.

DOE/EIA-0318(92), 486 pp., March 1995

GPO Stock No. 061-003-00904-2

Domestic, $\$ 31.00$; Foreign, $\$ 38.75$

\section{Mefaciata}

Annual Report to Congress 1994

This report highlights the Energy Information Administration's progress in 1994 toward fulfilling its mission and realizing its goals.

DOE/EIA-0173(94), 90 pp., April 1995

Call the National Energy Information Center on (202)586-8800 to request a free copy.

\section{U.S. Energy Industry Financial Developments 1994 Fourth Quarter} This report provides information on the financial performance of energy companies during the most recent reporting period.

DOE/ELA-0543(94/4Q), 28 pp., April 1995

Annual Subscription:

Domestic, $\$ 9.00$; Foreign, $\$ 11.25$

Single Issue: Domestic, \$2.25; Foreign, \$2.81

For a complete listing of the Energy Information Administration's (EIA) reports published in 1994, refer to EIA's Annual Report to Congress 1994. It is available, free of charge, from the National Energy Information Center at the following address:

National Energy Information Center Energy Information Administration EI-231, Forrestal Building

Washington, DC 20585

Internet E-Mail:

INFOCTR@EIA.DOE.GOV

TTY: For people who are deaf or hard of hearing: (202)586-1181

Hours: 9 a.m. to 5 p.m., M-F, eastern time.

Call the above telephone numbers for any energy-related information you may need. 
The Energy Information Administration (EIA) makes its machine-readable data files and modeling programs available through the National Technical Information Service (NTIS) (703)4874650. For a description of EIA's machine-readable products, contact the National Energy Information Center (NEIC) at (202)586-8800 (Internet E-Mail: INFOCTR@EIA.DOE.GOV) and request a copy of the EIA Directory of Electronic Products.
Data and model diskettes are available from the Department of Energy's Office of Scientific and Technical Information (OSTI). To order, call OSTI at (615)576-8401 and reference the diskettes by title.

Listed below are the most recently updated data files made available from NTIS and OSTI. \%

\section{NTIS}

\begin{tabular}{|c|c|c|c|}
\hline 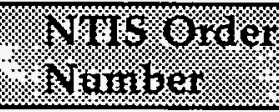 & א. & (4) & Dafes of \\
\hline PB93-592450 & Monthly & Monthly Power Plant Report (diskette) & $01 / 94-12 / 94$ \\
\hline PB91-591650 & Monthly & Monthly Energy Review Data Base (diskette) & $1973-03 / 95$ \\
\hline PB93-592460 & Monthly & $\begin{array}{l}\text { Monthly Electric Utility Sales and Revenue Report } \\
\text { (diskette) }\end{array}$ & $01 / 95-01 / 95$ \\
\hline
\end{tabular}

\section{OSTI (Diskettes)}

\begin{tabular}{|c|c|c|}
\hline Hrectrentiv: & 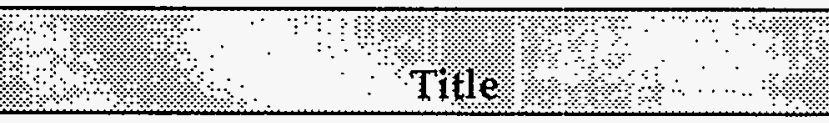 & $\begin{array}{l}\text { Dates of } \\
\text { Ooverage } \\
\end{array}$ \\
\hline Monthly & Monthly Energy Review Data Base & $1973-03 / 95$ \\
\hline Monthly & Monthly Power Plant Report & $01 / 94-12 / 94$ \\
\hline Monthly & Monthly Electric Utility Sales and Revenue Report & $01 / 95-01 / 95$ \\
\hline
\end{tabular}


Items listed in EIA New Releases can be ordered from one of four places: the National Energy Information Center (NEIC), the U.S. Government Printing Office (GPO), the National Technical
Information Service (NTIS), and the U.S. Department of Energy's Office of Scientific and Technical Information (OSTI). The chart below shows what can be ordered and from where.

\section{BtA Aroduct $\bullet ?$}

NEIC : GPO N NIS

요

Directories and EIA New Releases - current issues

Directories and EIA New Releases - back issues

For-sale publications - current issues

For-sale publications - back issues

Subscriptions

Machine-readable products

The category of publications called "Directories and EIA New Releases" is free to everyone. The category includes the following items: EIA New Releases, Energy Information Directory, EIA Directory of Electronic Products, EIA Publications Directory, Directory of Energy Data Collection Forms, Directory of Energy Information Model Abstracts, the Energy Information Administration's Annual Report to Congress, and all service reports and Energy Information Sheets. However, there is a charge for back issues from NTIS. (A current issue is one that is less than 1 year old.)

Publications and subscriptions normally for sale are free if ordered from NEIC by the following customers: Public, school, and university libraries; DOE contractors; employees of the media, Congress, and Federal, State, local, and foreign governments; and EIA survey respondents.

Subscriptions from GPO are available for weekly, monthly, and quarterly, but not for annual, publications.

\section{To Order from NEIC}

Call (202)586-8800 (TTY 202/586-1181; Internet E-Mail Address: INFOCTR@EIA.DOE.GOV) or use the form entitled "NEIC Orders" in the back of this report. This form should also be used if you have changed your address or if you want your name removed from the mailing list.

\section{To Order from GPO}

Single-Issue Publications and Subscriptions:

Call the GPO Main Order Desk at (202)512-1800

(FAX: (202)512-2250) or use the order form entitled "GPO Orders" in the back of this report.
\%

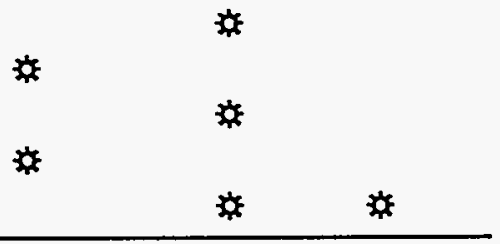

GPO accepts the following types of payment: check or money order made out to the Superintendent of Documents, credit card number and expiration date for VISA or MasterCard, or a GPO deposit account number. To open such an account, call (202)783-3238. Payment must be included before an order can be filled.

\section{To Order from OSTI}

\section{Personal Computer Diskettes:}

Call Request Services at (615)576-8401 or send your order to the following address: Office of Scientific and Technical Information, Request Services, P.O. Box 62, Oak Ridge, TN 37831.

OSTI accepts the following types of payment: check or money order made out to the United States Department of Energy, or credit card number and expiration date for VISA or MasterCard. Payment must be included before an order can be filled.

\section{To Order from NTIS}

To order from NTIS, call (703)487-4650 or use the order form entitled "NTIS Orders" in the back of this report.

Reports are available from NTIS in hard copy, microfiche, or paper copy reproduced from microfiche.

NTIS accepts the following forms of payment: check or money order made out to NTIS, VISA, MasterCard, or American Express, or an NTIS deposit account number. To open an NTIS deposit account, call (703)487-4770. Requests will not be processed unless payment accompanies the order, except in the case of "ship-and-bill" orders. 

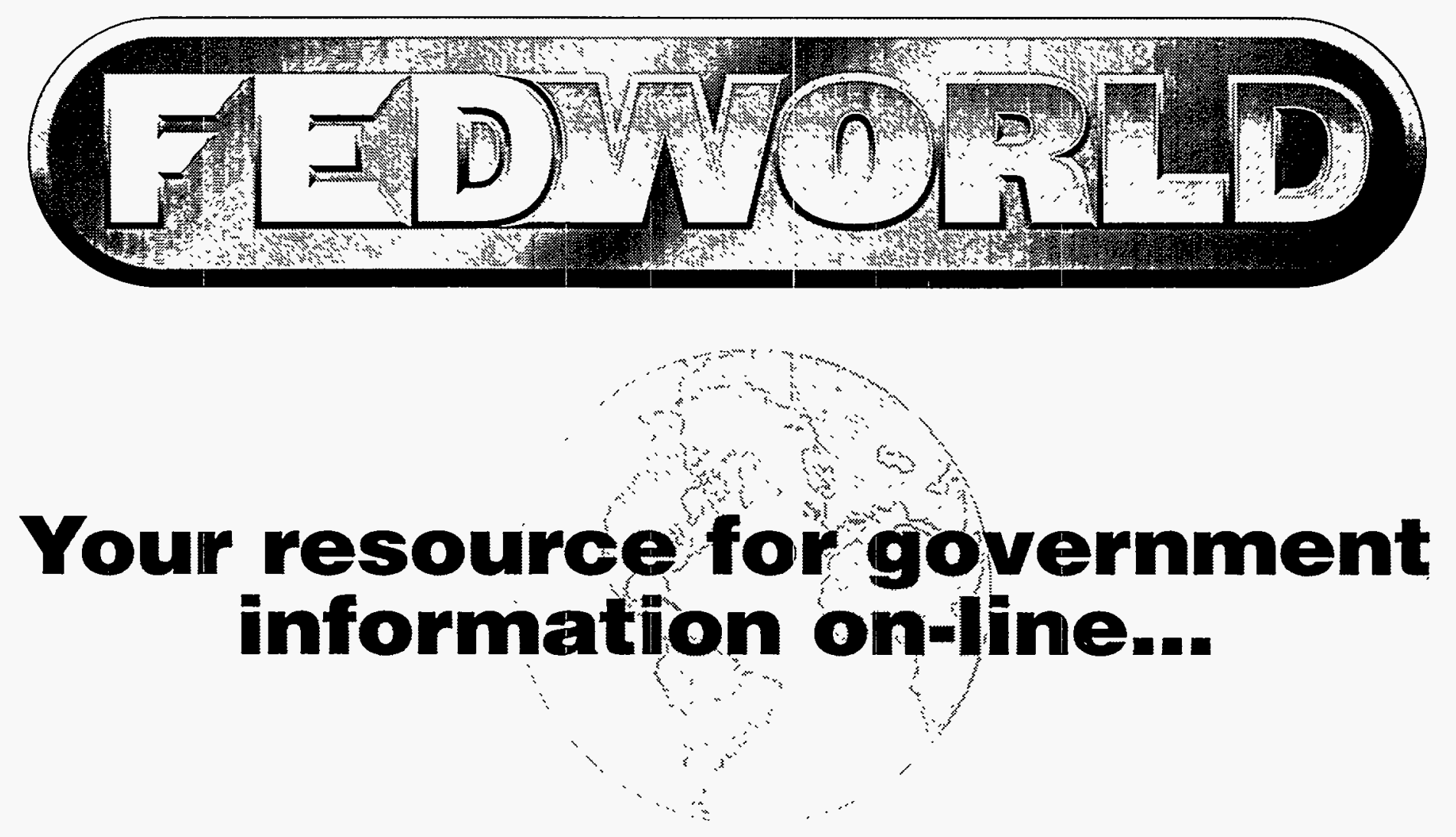

\begin{tabular}{|c|c|c|}
\hline $\begin{array}{l}\text { The FedWorld }{ }^{\top} \text { Information } \\
\text { Network is an on-line information } \\
\text { service established by the } \\
\text { National Technical Information } \\
\text { Service to provide the general } \\
\text { public with a user-friendly, central } \\
\text { resource for government } \\
\text { information in electronic formats. } \\
\text { FedWorld provides free dial-up } \\
\text { and Internet access to } \\
\text { information from many different } \\
\text { government agencies and } \\
\text { programs. }\end{array}$ & $\begin{array}{l}\text { NTIS receives thousands of } \\
\text { reports and documents from U.S. } \\
\text { government agencies each week. } \\
\text { With our new Thirty-day Preview } \\
\text { Database, FedWorld users can } \\
\text { now view abstracts of these } \\
\text { documents as they are added to } \\
\text { the collection. } \\
\text { Each abstract is accessible for } 30 \\
\text { days, until it is replaced by newer } \\
\text { material. FedWorld's sophisticated } \\
\text { search software will allow you to } \\
\text { locate and view these abstracts } \\
\text { easily. To find out more about } \\
\text { FedWorld, connect today. }\end{array}$ & $\begin{array}{l}\text { FedWorld Preview Dalabase } \\
\text { Connect to FedWorld with your } \\
\text { modem. The modem connection } \\
\text { number is (703) 321-FEDW (3339). } \\
\text { If you have access to Internet, } \\
\text { telnet to fedworld.gov. } \\
\text { Then, at the main menu, type /go } \\
\text { NTISPREV. For World Wide Web } \\
\text { Services, point your browser to } \\
\text { http:/lwww.fedworld.gov and click } \\
\text { on Recent U.S. Government } \\
\text { Reports. } \\
\text { For assistance, call the Help Desk } \\
\text { at (703) } 487-4608 \text {. }\end{array}$ \\
\hline
\end{tabular}

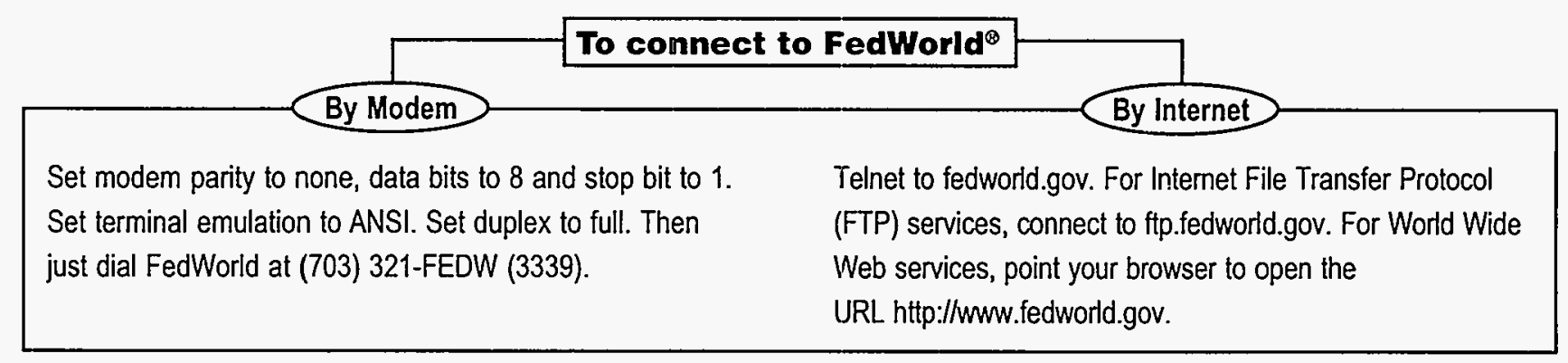


All telephone numbers are in area code 202, except where noted otherwise. Each FAX number applies to all names that follow. Each Internet name is followed with @eia.doe.gov

\begin{tabular}{|c|c|}
\hline Hor Specific Data 1 rea & Interne \\
\hline
\end{tabular}

COAL:

Annual Mining and Production

Consumption

Distribution

Exports

Monthly Data

Producer/Distributor Stocks

Production and Consumption

Quarterly Data

Reserves

Short-Term Coal Projections

Stocks

Weekly Production

ELECTRIC POWER: Nonutility

Capacity, Generation, Fuel Consumption, and Sales to Grid

Generation

Renewable Energy Use

Short-Term Nonutility Sales Projections

ELECTRIC POWER: Utility

Demand-Side Management

Emissions

Utility Boiler Design

Utility Bulk Power Transmission

Utility Capacity

Utility Repowering

Utility Life Extension

Utility Financial Data Systems

Utility Finance, Investor-Owned

Utility Finance, Publicly Owned

Utility Fuel Consumption

Utility Fuel Receipts

Utility Fuel Cost and Quality

Utility Fuel Stocks/Generation

Utility Power Production Expenses

Short-Term Hydroelectric Power Projections

Short-Term Electricity Imports Projections

(Continued on next page.)

\begin{tabular}{lll} 
FAX Number: & $\mathbf{2 5 4 - 5 7 6 5}$ & \\
\hline Fred Freme & $254-5367$ & ffreme \\
Steve Scott & $254-5467$ & sscott \\
Mary Lilly & $254-5391$ & mlilly \\
Tom Murphy & $254-5561$ & tmurphy \\
Paulette Young & $254-5481$ & pyoung \\
Paulette Young & $254-5481$ & pyoung \\
Tom Murphy & $254-5561$ & tmurphy \\
Mary Paull & $254-5379$ & mpaull \\
Paulette Young & $254-5481$ & pyoung \\
Richard Bonskowski & $254-5383$ & rbonskow \\
Willie Hong & $254-5365$ & bhong \\
Mary Paull & $254-5379$ & mpaull \\
Mary Lilly & $254-5391$ & mlilly \\
& & \\
FAX Number: & $254-5765$ & \\
\hline John Colligan & $254-5465$ & jcolliga \\
Betty Williams & $254-5656$ & bwilliam \\
Robin Reichenbach & $254-5353$ & rreichen \\
Larry Prete & $254-5671$ & lprete \\
Robin Reichenbach & $254-5353$ & rreichen \\
& & \\
FAX Number: & $254-5765$ & \\
\hline Linda Bromley & $254-5653$ & lbromley \\
John Colligan & $254-5465$ & jcolliga \\
John Colligan & $254-5465$ & jcolliga \\
John Makens & $254-5629$ & jmakens \\
Elsie Bess & $254-5637$ & ebess \\
Karen McDaniel & $254-5672$ & kmcdanie \\
Arthur Fuldner & $254-5321$ & afuldner \\
Arthur Fuldner & $254-5321$ & afuldner \\
Lucinda Gilliam & $254-5438$ & lgilliam \\
Jerry Sanderson & $254-5463$ & jsanders \\
C. Harris-Russell & $254-5437$ & charrisr \\
Deborah Bolden & $254-5663$ & dbolden \\
Melvin Johnson & $254-5665$ & mejohnso \\
Kenny McClevey & $254-5655$ & kmccleve \\
Kenny McClevey & $254-5655$ & kmccleve \\
Deborah Bolden & $254-5663$ & dbolden \\
Melvin Johnson & $254-5665$ & mejohnso \\
Elsie Bess & $254-5637$ & ebess \\
Robin Reichenbach & $254-5353$ & rreichen \\
Robin Reichenbach & $254-5353$ & rreichen \\
\hline
\end{tabular}


All telephone numbers are in area code 202, except where noted otherwise.

Each FAX number applies to all names that follow.

Each Internet name is followed with @eia.doe.gov

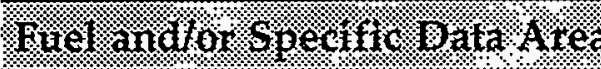 \\ Electric Power: Utility (cont'd) \\ Statistical Reports}

Utility Sales and Revenue

NUCLEAR POWER:

Capacity and Generation

Domestic and Foreign Nuclear Power Capacity

and Generation

Foreign Nuclear Power

Fuel Cycle Requirements Projections

Short-Term Nuclear Generation Projections

Spent Fuel Projections

Waste Characteristics

Waste Fund Fees

\section{URANIUM:}

Decommissioning

Demand/Requirements

Exploration and Industry Employment

Marketing, Imports/Exports

Production, Prices

Resources/Reserves

RENEWABLE ENERGY:

Alternative-Fueled Vehicles

Alternative Transportation Fuels

Biomass/Biofuels

Geothermal

Renewable Resources Assessment

Solar Collector, Photovoltaic

Solar Collector Cells/Modules

\section{NATURAL GAS:}

Coalbed Methane/Tight Gas

Consumer and City Gate Prices

Consumption (by sector)

Drilling

Exploration

Futures Market

Imports/Exports

Liquefied Natural Gas Storage

Natural Gas Liquids

Natural Gas Vehicles

Pipeline Capacity

Nane $1 . \%$ Telephone Iriternet

\begin{tabular}{lll} 
FAX Number: & $254-5765$ & \\
\hline Sandra Smith & $254-5632$ & $\begin{array}{l}\text { ssmith } \\
\text { dbolden } \\
\text { Deborah Bolden }\end{array}$ \\
$\begin{array}{l}\text { Stephen Calopedis } \\
\text { Linda Bromley }\end{array}$ & $254-5663-5661$ & $\begin{array}{l}\text { scaloped } \\
\text { lbromley }\end{array}$ \\
& $254-5653$ & \\
FAX Number: & $254-5765$ & \\
\hline Doug Bonnar & $254-5560$ & dbonner \\
Kenneth C. Wade & $254-5514$ & kwade
\end{tabular}

Doug Bonnar 254-5560 dbonner

William Liggett 254-5508 wliggett

Kenneth C. Wade 254-5514 kwade

William Liggett 254-5508 wliggett

Kathy Gibbard 254-5559 kgibbard

Jorge Luna-Camara 254-5664 jlunacam

\begin{tabular}{|c|c|c|}
\hline FAX Number: & 254-5765 & \\
\hline Taesin Chung & $254-5556$ & tchung \\
\hline William Liggett & $254-5508$ & wliggett \\
\hline Charles Johnson & $254-5568$ & cjohnson \\
\hline Doug Bonnar & $254-5560$ & dbonnar \\
\hline Doug Bonnar & $254-5560$ & dbonnar \\
\hline Taesin Chung & $254-5556$ & tchung \\
\hline FAX Number: & 254-5765 & \\
\hline Jim Disbrow & $254-5558$ & jdisbrow \\
\hline Jim Disbrow & $254-5558$ & jdisbrow \\
\hline Robert Lowe & $254-5557$ & rlowe \\
\hline Peter Holihan & $254-5432$ & jholihan \\
\hline Mark Gielecki & $254-5320$ & mgieleck \\
\hline Peter Holihan & $254-5432$ & jholihan \\
\hline Peter Holihan & $254-5432$ & jholihan \\
\hline
\end{tabular}

FAX Number: $\quad \mathbf{5 8 6 - 1 0 7 6}$

\begin{tabular}{lll}
\hline Bob King & $586-4787$ & rking \\
Roy Kass & $586-4790$ & nkass \\
Roy Kass & $586-4790$ & nkass \\
Bob King & $586-4787$ & rking \\
Dave Morehouse & $586-4853$ & dmorehou \\
John Herbert & $586-4360$ & jherbert \\
Norm Crabtree & $586-6180$ & ncrabtre \\
James Tobin & $586-4835$ & jtobin \\
David Hinton & $586-2990$ & dhinton \\
Rosemary Jameson & $586-6229$ & rjameson \\
James Tobin & $586-4835$ & jtobin \\
\hline
\end{tabular}
James Tobin

(Continued on next page.) 
All telephone numbers are in area code 202, except where noted otherwise. Each FAX number applies to all names that follow. Each Internet name is followed with @eia.doe.gov

Fuel and 10 Specific Dara Alrea

Natural Gas (cont'd):

Pricing Analysis

Production

Productive Capacity

Regulatory Issues

Reserves

Resources

Rigs Count

Spot Market

Supply Analysis

Underground Storage

Wellhead Prices

PETROLEUM: Markets

Crude Oil/Wellhead Value

Domestic Crude Oil First Purchase Report

Domestic Crude Oil Markets

Domestic Products/Prices

Fuel Oil Sales

Petroleum Demand Analysis

Petroleum Futures Market Analysis

Petroleum Inventory Analysis

Refineries/Acquisition Cost

\section{PETROLEUM: Supply}

Crude Oil Production

Exports

Imports

Natural Gas Processing

Oxygenate Data

Propane Data

Refinery Operations

Stocks

Supply and Disposition

Transportation

Weekly Petroleum Status Report

OIL AND GAS: Production and Reserves

Drilling and Rigs Count

Production

Resources
Name

FAX Number:

Mary Carlson

Donna Guerrina

James Hicks

Joan Heinkel

John Wood

Dave Morehouse

Bob King

James Keeling

James Tobin

Rosemary Jameson

Donna Guerrina

FAX Number:

Alan Griffith

Alan Griffith

Alan Griffith

Charles Riner

Kenneth Platto

Alice Lippert

Charles Dale

Charles Dale

Alan Griffith

Elizabeth Scott

FAX Number:

David Hinton

John Nealey

Claudette Graham

David Hinton

Irv Chamberlain

David Hinton

Evie Harper

Mike Conner

Nancy Masterson

Mike Conner

Larry Alverson

FAX Number:

Bob King

Yousufuddin Mir

Dave Morehouse Tetephone Interiet

586-1076

586-4749

586-6135

(214)767-2200/

FAX: 767-2204

$586-4680$

(214)767-2200/

FAX: 767-2204

586-4853

586-4787

586-6107

586-4835

586-6229

586-6135

586-5846

586-7225

586-7225

586-7225

586-6610

586-6364

586-9600

586-1805

586-1805

586-7225

586-1258

agriffit

agriffit

agriffit

criner

kplatto

alippert

cdale

cdale

agriffit

escott

586-5846

586-5994

586-9670

586-9649

586-2990

586-9594

586-2990

586-5786

586-1795

586-8393

586-1795

586-9664

dhinton

jnealey

cgraham

dhinton

ichamber

dhinton

eharper

mconner

nmasters

mconner

lalverso

586-1076

586-4787

(214)767-2200/

rking

myousufu

FAX: 767-2204

$586-4853$ dmorehou

(Continued on next page.) 
Fuel and/or Specifict Data Area
OIL AND GAS: Production and Reserves (cont'd)

Reserves

MULTIFUEL: Consumption

Commercial Buildings Sector Characteristics, Con-

sumption, and Expenditures

Commercial Buildings Sector Analysis of Consumption and Conservation Trends

Integrated Historical Data

Manufacturing Sector Characteristics, Consumption and Expenditures

Manufacturing Sector Analysis of Consumption and Conservation Trends

Residential Sector Characteristics, Consumption and Expenditures

Residential Sector Analysis of Consumption and Conservation Trends

Residential Transportation Sector Characteristics, Consumption, and Expenditures

Residential Transportation Sector Analysis of Consumption and Conservation Trends

State-Level Consumption, Prices, and Expenditures

Transportation Program Development Related to Alternative Fuels

\section{INTERNATIONAL:}

International Energy Analysis; Petroleum and Contingency Analysis

International Energy Statistics; Country Production and Consumption of Major Fuels

\section{ECONOMIC:}

Corporate Finance

Energy Taxation

Foreign Investment

\section{FORECASTS:}

Annual Energy Outlook/Midterm Projections

Coal Production/Minemouth Prices/Midterm Projections

Coal Distribution/End-Use Prices/Midterm

$$
\text { Projections }
$$

Coal Exports/Midterm Projections

Commercial Demand/Midterm Projections

Crude Oil Supply/Midterm Projections
John Wood
FAX:767-2204

FAX Number:

586-0018

Martha Johnson

586-1135

mjohnson

Eugene Burns

586-1125

eburns

Samuel E. Brown

John Preston

586-5103

586-1128

sbrown

John Preston

586-1128

jpreston

Wendel Thompson

586-1119

jpreston

Wendel Thompson

586-1119

wthompso

Ron Lambrecht

$586-4962$

wthompso

Ron Lambrecht

$586-4962$

rlambrec

Julia F. Hutchins

Leigh Carleton

586-5138

586-1132

rlambrec

jhutchin

lcarleto

\begin{tabular}{lll} 
FAX Number: & $586-9753$ & \\
\hline Derriel Cato & $586-6574$ & dcato \\
Louis DeMouy & $586-6557$ & ldemouy
\end{tabular}

FAX Number:

586-9753

Jon A. Rasmussen

586-1449

jrasmuss

Dennis W. Sumner

586-8597

dsumner

Jon A. Rasmussen

586-1449

jrasmuss

FAX Number:

586-3045

Susan H. Shaw

586-4838

sshaw

Michael Mellish

586-2136

mmellish

Richard Newcombe

586-2415

rnewcomb

Melinda Hobbs

586-2152

mhobbs

Barry N. Cohen

586-5359

bcohen

William A. Trapmann

wtrapman

(Continued on next page.) 
All telephone numbers are in area code 202, except where noted otherwise.

Each FAX number applies to all names that follow.

Each Internet name is followed with @eia.doe.gov

\begin{tabular}{|c|c|c|c|}
\hline 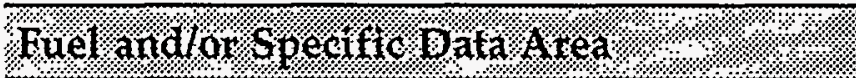 & Mame & Yelephionie & Iriternet \\
\hline FORECASTS (cont'd): & FAX Number: & $586-3045$ & \\
\hline Electricity Generation and Cost/Midterm Projections & J. Alan Beamon & $586-2025$ & abeamon \\
\hline Electricity Prices/Midterm Projections & Art Holland & $586-2026$ & aholland \\
\hline Greenhouse Gases & Arthur Rypinski & $586-8425$ & arypinsk \\
\hline Industrial Demand/Midterm Projections & T. C. Honeycutt & $586-1420$ & choneycu \\
\hline International/Midterm Projections & A. David Sandoval & $586-6581$ & -- \\
\hline \multirow[t]{2}{*}{ Macroeconomic Analysis/Midterm Projections } & Ronald F. Earley & $586-1398$ & rearley \\
\hline & Kay A. Smith & $586-1455$ & ksmith \\
\hline \multirow[t]{2}{*}{ National Energy Modeling System } & Mary J. Hutzler & $586-2222$ & mhutzler \\
\hline & Susan H. Shaw & $586-4838$ & sshaw \\
\hline Natural Gas Markets/Midterm Projections & James Diemer & $586-6126$ & jdiemer \\
\hline Natural Gas Supply/Midterm Projections & William A. Trapmann & $586-6408$ & wtrapman \\
\hline $\begin{array}{l}\text { Nuclear Energy, Domestic and International/ } \\
\text { Midterm and Long-Term Projections }\end{array}$ & Robert T. Eynon & $586-2315$ & reynon \\
\hline Petroleum Product Markets/Midterm Projections & Bruce Bawks & $586-6579$ & bbawks \\
\hline Renewable Energy/Midterm Projections & Perry Lindstrom & $586-0934$ & plindstr \\
\hline Residential Demand/Midterm Projections & Barry N. Cohen & $586-5359$ & bcohen \\
\hline $\begin{array}{l}\text { Short-Term Energy Forecasts--Supply, Demand, } \\
\text { and Prices }\end{array}$ & David W. Costello & $\begin{array}{c}586-1468 / \\
\text { FAX: } 586-9753\end{array}$ & dcostell \\
\hline Transportation Demand/Midterm Projections & David Chien & $586-3994$ & dchien \\
\hline World Oil Prices/Midterm Projections & G. Daniel Butler & $586-9503$ & gbutler \\
\hline STANDARDS AND STATISTICAL METHODS: & FAX Number: & 254-9700 & \\
\hline Data and Modeling Quality & Doug Hale & $254-5380$ & dhale \\
\hline EIA Metric Program & Jay Casselberry & $254-5348$ & jcasselb \\
\hline EIA Standards Program & Jay Casselberry & $254-5348$ & jcasselb \\
\hline
\end{tabular}




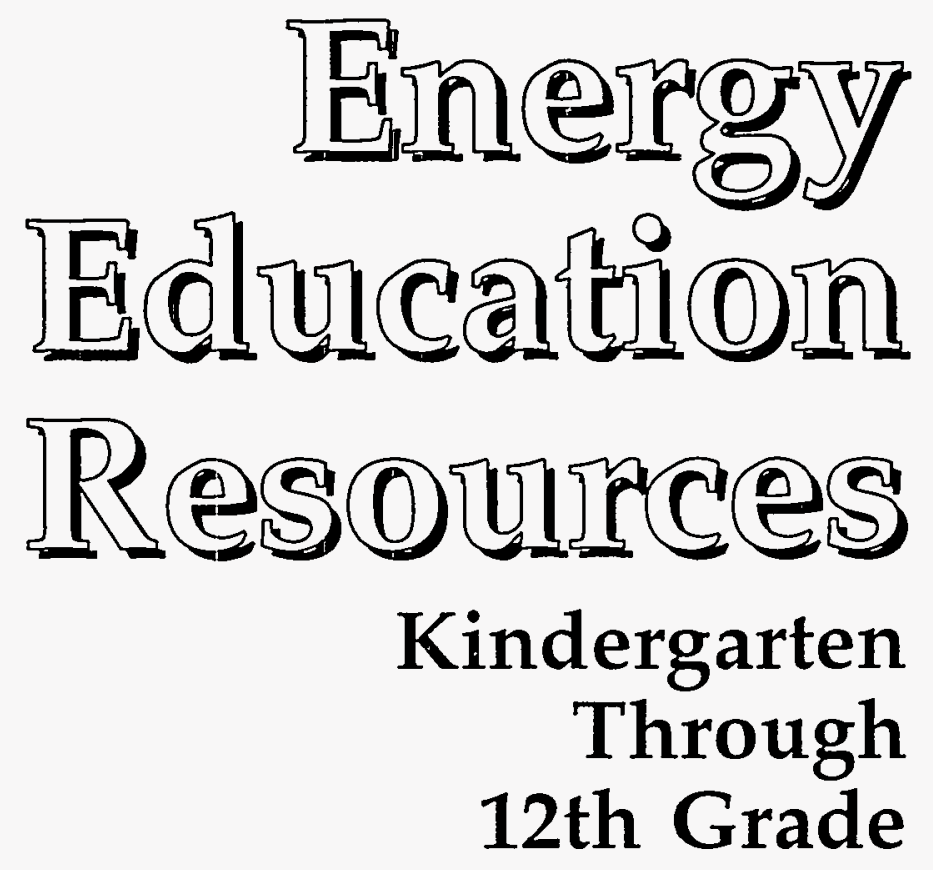

This brochure contains a listing of free or low-cost energy-related educational materials for educators and primary and secondary students.

Call the National Energy Information Center on (202)586-8800 to order your free copy. 


\section{GPO Orders}

Order Processing Code:

7696

Superintendent of Documents Publications and Subscriptions Order Form

Charge your order.

It's Easy!

To fax your orders (202) 512-2250

Publications

Please Type or Print (Form is aligned for typewriter use.)

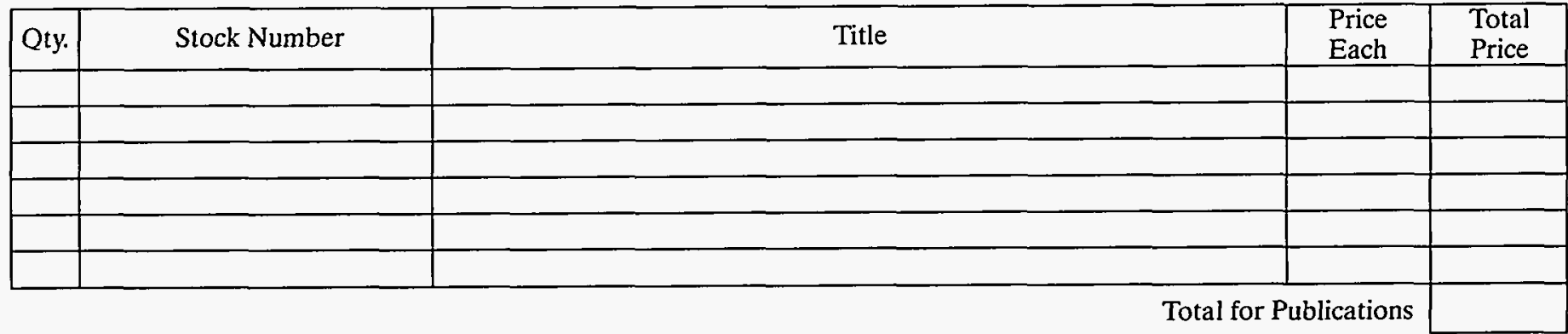

\section{Subscriptions}

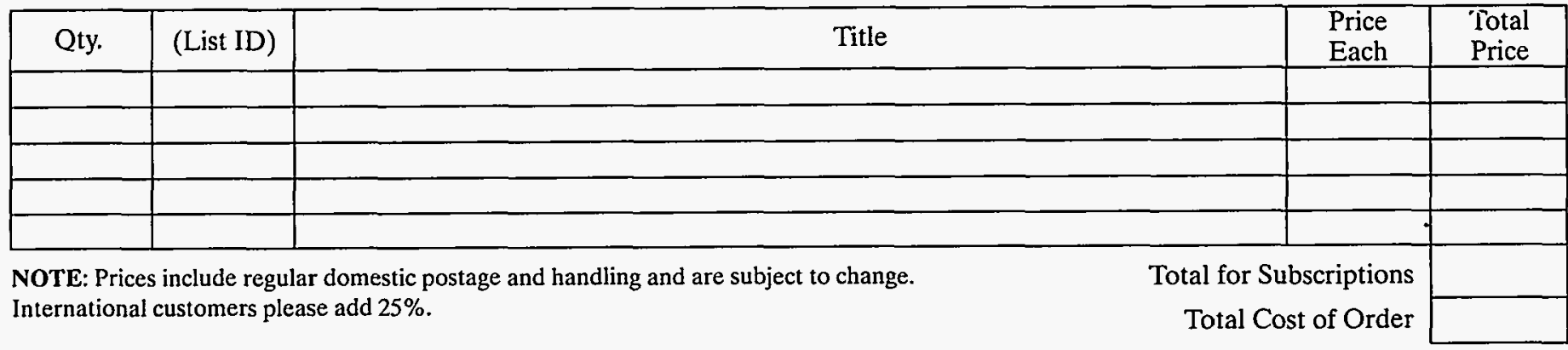

(Company or Personal Name)

(Please type or print)

(Additional address/attention line)

(Street address)

(City, State, ZIP Code)

(Daytime phone including area code)

(Purchase Order No.)

Mail To: Superintendent of Documents P.O. Box 371954, Pittsburgh, PA 15250-7954
For privacy protection, check the box below:

$\square$ Do not make my name available to other mailers Please choose method of payment:

$\square$ Check Payable to the Superintendent of Documents

$\square$ GPO Deposit Account

$\square$ VISA or MasterCard Account

\begin{tabular}{|l|l|l|l|l|l|l|l|l|l|l|l|l|l|l|l|l|l|}
\hline & & & & & & & & & & & & & & & & & \\
\hline
\end{tabular}

(Credit card expiration date)

Thank you for your order!

(Authorizing Signature)

May 1995 


\section{NTIS Orders}

U.S. DEPARTMENT OF COMHERCE

TECHNOLOGY ADMINISTRATION

\section{ORDER FORM}

WIS

\section{SHIDP TO ADDRESS}

CUSTOMER MUSTER NUMBER (IF KNOWN)

ATENTIONHULE

$\frac{2}{2}$

DRGANIZATON

DMSTONI ROOM MUMBER

STREET ADORESS

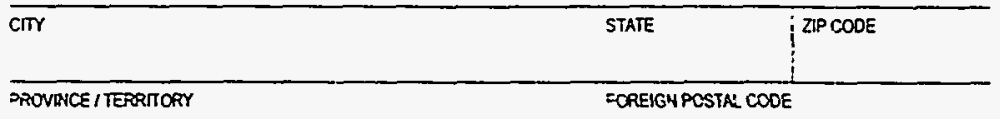

COUNTRY

\begin{tabular}{ll}
\hline PHONE NUMBER & FAX MUMBER \\
& 1 \\
\hline
\end{tabular}

CONTACT NAME

\section{METHOD OF PAYMENT}

$\square$ Check / Money Order enclosed for \$

(PAYABLE N US DOLARST

口NTIS Deposit Account Number.

$\square$ VISA

D MasterCard

$\square$ American Express

CREOIT CARO NUMBER

SXPIRATION DATE

CAROHOLOERS NAME

SIGNATURE RREOURED TO VAL WATE ALL OPDERS)

\section{DTIC USER'S ONLY}

COOE

CONTRACT NUMBER RAST SQX DEGTS

ORDER BY PHOHE (ENGUTE WAR TME)

3:30 a.m. $\cdot$ 5:00 0.m. Eastern Time. $M-F$.

Sales Desk: (703) 487.4650

Subscriptions: (703) 487.4630

DD (hearing umpared only): (703) 487-4639

\section{OADER BY FAX}

24 hours 7 days a week: (703) 321-8547

- 5 venfy receipl of fax: call (703) $487-4679$

7.00 a.m. - 5:00 0.m., Eastem Time. $M-F$.

ORDER BY MALL

National Techncal Informaton Service

\$285 Port Royal Road

sxingfield, VA 22161

RUSH SERVICE (DO NOT WU RUSH ORDERS)

-800-553-NTIS

FUSH service avalable for acditonal fee.

FEDWORLD

Pease call for connect information: (703) $487-4608$.

BILL ME

.U.S. Canada. and Mexico only.

DO NOT USE THIS FORH.

VTIS will gladly bill your oroer. for an additional fee of

57.50. A request to be billed must be on a ourchase order x company letterhead. An authorizing signaure, contact

ame, and telephone number snould be incerded with this equest. Requests may be maried or laxed.

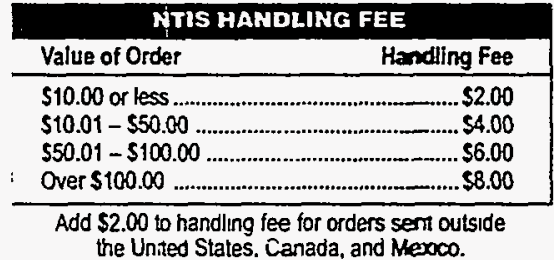

\section{PRODUCT SELECTION}

\begin{tabular}{|c|c|c|c|c|c|c|c|c|c|c|}
\hline \multirow{2}{*}{\multicolumn{2}{|c|}{$\begin{array}{l}\text { NTIS PRODUCT NUMBER } \\
\text { SORDERING BY TIRE ALONE } \\
\text { WIL DELAY YOUR ORDERI }\end{array}$}} & \multirow{2}{*}{$\begin{array}{l}\text { PTEPHAL CUSTOMER } \\
\text { ROUTHG (OPTIOMAM } \\
\text {.P TO \& CHAPACTERS }\end{array}$} & \multirow{2}{*}{$\begin{array}{l}\text { UNT } \\
\text { PRXEE }\end{array}$} & \multicolumn{5}{|c|}{ QUANTIT } & \multirow{2}{*}{$\begin{array}{l}\text { MTERATOMUL } \\
\text { ARMUR FEE } \\
\text { SEE BEIOW }\end{array}$} & \multirow{2}{*}{ TOTAL PRICE } \\
\hline & & & & $\begin{array}{l}\text { PAPER } \\
\text { COFY }\end{array}$ & $\begin{array}{l}\text { MICRO- } \\
\text { FICHE }\end{array}$ & $\begin{array}{l}\text { MAGNETIC } \\
\text { TAPE * }\end{array}$ & DSAE-TE & CO-ROM OTHER & & \\
\hline & $A G X$ & & $\$$ & & & 1 & & & 5 & 5 \\
\hline & $A G X$ & & $S$ & & & 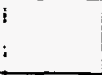 & & & $\$$ & 5 \\
\hline & $A G X$ & & $\$$ & & & 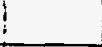 & & & $\$$ & 5 \\
\hline & $A G X$ & & $\$$ & & & 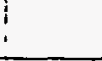 & & & 5 & 5 \\
\hline & $A G X$ & & $\$$ & & & 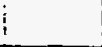 & & & s & 5 \\
\hline \multirow{2}{*}{ 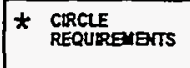 } & \multirow{2}{*}{$\begin{array}{c}3480 \\
\text { CARTRIDGE }\end{array}$} & \multirow{2}{*}{$\begin{array}{l}i 600 \\
891\end{array}$} & \multicolumn{2}{|c|}{ LABELIMG } & \multicolumn{3}{|c|}{ FORMAT } & \multirow{2}{*}{\multicolumn{2}{|c|}{ TOTAL }} & \multirow[b]{2}{*}{15} \\
\hline & & & STANDARD & NONLABELED & & $\operatorname{colc}$ & AsCa & & & \\
\hline
\end{tabular}

PLEASE MOTE

Unless microfiche or other is speafied. Daper copy will be sent

Please call the Sales Desk at (703) 487.4650 for infomaton on mutuple copy discounts avadable for certan documents. retum policy, and price verfication.

Out-Of-Print Surcharge

Effective $4 / 17 / 95$, an out-of-prnt surcharge may apply to certain ttles acquired by NTIS more than three years proc of the current calenoar year, please call to verivy price.

International Airmail Fees

Canada ano Mexico add $\$ 4$ per paper copy report $\$ 1$ per mocrofiche copy. Other countries add $\$ 8$ per paper copy reocrt:

$\$ 1.25$ per mocrofiche copy. (Paper copy reports and microfiche copies are shipped surface mal unless airmal is specfied.)

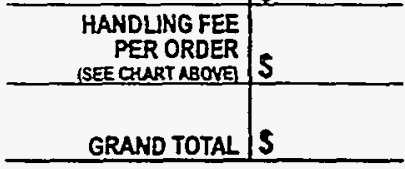

Thank you for seace ardert Prices are subject to change.

All previous versions of this form are obsolete. 


\section{NATIONAL ENERGY INFORMATION CENTER ORDER FORM}

TO ORDER FREE PUBLICATIONS--TO NOTIFY NEIC OF CHANGE OF ADDRESS --TO CANCEL A MAILING LIST PUBLICATION

Mail to: National Energy Information Center, El-231 Energy Information Administration

Room 1F-048, Forrestal Building

Washington, DC 20585

\section{Name}

Business Affiliation

\section{Address}

City and State Zip Code

$(\quad)$

Phone number with area code
Mail List I.D. Number (Found in upper left corner of your mailing label.)

$(1)$

FAX Number

Change of address.

$\square$ Add name to mailing list for free publication(s) as listed below.

$\square$ Take name off mailing list for publication(s) as listed below.

$\square$ Send the free publication(s) as listed below. 